cised in good faith. Support for this view might be found in the analogy that the exercise of a power of appointment will be void as a fraud on the power if the donee merely fails to carry out the donor's purpose.110 But the analogy is not compelling, for the object of the rule concerning powers of appointment is to avoid "defrauding" the donor, while here the only person who might be considered "defrauded" is the displaced beneficiary. And a beneficiary whose interests are thus destroyed has not been unduly prejudiced since, from their inception, his interests were subject to divestment by any exercise of the reserved power of alteration. Inasmuch as the settlor clearly had the power under the instrument to invest himself with the whole beneficial interest of the trust, it seems that nothing is to be gained by vithholding the legal interest.

\title{
STATE HOMESTEAD EXEMPTION LAWS
}

State Homestead laws exempting the debtor's home within designated limits of space and value from judicial sale at the suit of creditors are a familiar part of the American legal scene. 1 The absence of any recent or relatively brief discussion of this segment of the law suggests a study of its legislative and judicial history, comparable legal trends in other countries, and the present developments in this field in the United States.

Homestead laws are essentially American in their origin. ${ }^{2}$ A precedent for such enactments has indeed been found by the courts in the early common law where feudal principles forbade the alienation or encumbrance of the fief. ${ }^{3}$ There is no evidence, however, that this land law, serving its

110. See (1936) 46 YarE L. J. 344.

1. These laws must be distinguished from the federal homestead legisistion, rhich seeks to encourage the colonization of outlying districts by granting the qualified applicant a quarter section or less of unappropriated public land after he has occupiad and cultivated it for a certain period. This land is exempt from all debts contracted prior to the acquisition of title but not from those incurred thereafter. REv. STar. §ुऽ 2209, 2291, 2296 (1875), 43 U. S.C. $\$ \$ 161,164,175$ (1934). State homestead lings, on the other hand, affect land already owned by the beneficiary and only exempt it from debts incurred subsequent to its dedication. WAPLES, Horsestend ast ExEzomnon (1893) 924.

Federal homestead legislation is beyond the scope of this Comment. For a brief discussion, see id., at 924-953.

2. Roten, Asiles de FandrLle en Suisse (1926) 17; Vance, Homestead Exemption Laws (1932) 7 Encyc. Soc. Scrences 441.

3. In re Vogler, 28 Fed. Cas. No. 16,986 (W.D. N.C. 1873); Norton v. Bradham, 21 S. C. 375 (1884); see Trosspson, Hosrestend aNd Exzzrption LAN/S (1878) 84.

By the nineteenth' century the debtor's lands could generally be subjected to gale for the nonpayment of his debts. Prather, Economic Effects of the Homesteed cond Exemption Lows (Unpublished thesis in New York Public Library, 1903) 17-18 
special political ends, had any influence upon the proponents of homestead legislation, and the alleged connection seems an afterthought on the part of the American courts, seeking to justify their conclusion that these laws should be liberally rather than strictly construed. ${ }^{4}$ The earlier laws dealing with chattel exemptions appear to be the true forerunner of homestead legislation. ${ }^{5}$ In the United States, the first third of the nineteenth century was the heyday of prosecutions for debt, and the unfortunate condition of the debtor aroused the attention of legislators and philanthropists. ${ }^{\circ}$ America, with its primitive conditions, was also peculiarly interested in encouraging the pioneer, and protecting him against the financial hazards of his life. It is therefore not surprising to find the rise of chattel exemption laws, which, although they have their prototypes in common law rules, ${ }^{7}$ were a response to frontier conditions, ${ }^{8}$ and, like the indulgent bankruptcy laws, a manifestation of the political influence exerted by the small-debtor class throughout the history of American life. ${ }^{9}$ The main functions of such laws were to protect the family, ${ }^{10}$ to enable the debtor to retain his independent status and to encourage the pursuit of professions or skilled trades. ${ }^{11}$ These laws spread rapidly throughout the Union, ${ }^{12}$ and exist today in all of the states and in the District of Columbia, as well as in numerous foreign countries. ${ }^{10}$

4. See Vance, loc. cit. supra note 2. It is significant that no reference to this feudal land law appears to have been made in the various constitutional and legislative debates on homestead exemptions. See VAcher, Le Homestead aUX Etats-Unis (1895) 121.

5. See VACBER, loc. cit. supra note 4.

6. 5 Channing, History of the United States (1930) 192; see Vermont Chronicle, Jan. 24, 1849, p. 13, col. 2.

7. At an eariy date restrictions were placed upon the distraint of chattels necessary to the debtor's economic existence. $51 \mathrm{HEN}$. 3, st. 4 (1266) (no distress upon sheep); 52 HEN. 3, c.c. 1, 2, 4, 15 (1267) (penalties prescribed for unlawful distress); 28 EDw. 1, c. $12(1300)$ (beasts of the plough to be distrained upon only as a last resort).

8. See Vance, supra note 2 , at 442.

9. See Warren, Bankruptcy in United States History (1935) 49-92.

10. This is indicated by the fact that often their benefits were restricted to heads of families, that the right of exemption frequently passed upon the death of the owner to the surviving spouse and children, and that the chattels usually exempted included family clothing, household furniture, necessary provisions and such tools as were necessary to enable the breadwinner to continue in his trade or profession. Typical among the early statutes are Me. Laws 1821, c. 95; Mass. Laws 1805, c. 100; N. Y. Laws 1810 , appearing in 6 Webster, LAws of NEW YoRK (1812) 83; Tenn. Laws 1833, c. 80.

11. See Sallee v. Waters, 17 Ala. 482, 489 (1850) ; Lambeth v. Milton, 2 Rob. 81, 82 (La. 1842); Harrison v. Martin, 7 Mo. 286, 287 (1842).

12. By 1845 , at least fifteen states had chattel exemption laws. Prather, op. cit. supra note 3 , at 18 .

13. See, e.g., 2 Alberta Rev. Stat. (1922) 1113-1114; 2 Manitoda Rev. Stat. (1913) $1025-1027$. 
The first step towards the enactment of comparable legislation to preserve the family hearth is to be found in Texas, which at that time was under Mexican government and far removed from the inhibitions of the common law. ${ }^{14}$ In 1821, Moses Austin secured through the governor of Texas a huge grant of land on which to establish three hundred families. Austin's grant was followed by similar grants to other impresarios until substantially all of Texas was laid open to immigration, and within ten years the population of Texas had increased to twenty thousand. ${ }^{15}$ Many of these immigrants had left the United States in an effort to escape from their creditors, ${ }^{10}$ and this circumstance led Austin's son and successor, Stephen, to propose a stay law exempting their property in Texas for twelve years from execution to pay debts contracted before immigration, in order that they might be given an opportunity to develop their lands properly.17 In supporting this legislation, Austin relied not only upon its economic advantages, but also had recourse to a Spanish precedent, ${ }^{18}$ which, antedating the American chattel exemptions by several centuries, was similar to them in scope and effect. ${ }^{10}$ Whichever argument prevailed, a law was passed in 1829 providing that lands acquired by virtue of the colonization laws should not be subject for a period of twelve years to the payment of debts contracted previous to their acquisition, and declaring that after that time the colonists should be obligated to pay them only in money or products "in a manner not to affect their attention to their families, their husbandry, or art they profess." Farming utensils and implements of trade were also specifically exempted.9 This

14. 1 BeARd, Rise of Axferican Civirization (1928) 587; Vance, suspa note 2, at 442 . 225.

15. 1 Beard, loc. cit. supra note 14 ; cf. 1 Foote, Texas astd taf Texasis (18A1)

16. Edward, History of Texas (1836) 179; Stifp, Texan Eumgrant (1840) 53 It has been suggested, however, that a primary factor contributing to this immigration was the fear experienced by many southerners that slavery would shortly be abolisted in the United States. See Fourxer, Le Texas (1841) 42.

17. Memorial to the Legislature, Dec. 22, 1824 [reprinted in 2 BAnזEr, Tre Ausmr Papers (1919) 996-1000]; see Barker, Life of Steparen F. Austin (1926) 221.

18. Letter from Austin to Zavala, June 24, 1828 [reprinted in 2 BAnkEs, TrE Austrn PAPERS (1922) 47-51].

19. A translation of this law is to be found in 1 White, NEw Collection of LAws, Cemarters and Local Ordinances of Great Britain, France amd Spain (1839) 322324. This law has often been considered a precedent for the subsequent chattcl exemption and homestead statutes. See Cobbs v. Coleman, 14 Tex. 594, 598 (1855); Nonn, Texas Honestead (1931) 2; Wooten. History of Texas (1899) 273.

20. Knnball, Lau's and Decrees of the State of Comanuma and Texas (1839) 110-111. There are indications that this law relieved a good deal of anxicty among the colonists. See letter from Peter Ellis Bean to Austin, March 18, 1829 [reprinted in 2 BARKER, op. cit. supra note 18, at 192]: "I gave you thanlis for the Copey of the Law that Delebrate the Settlers of this Cuntrey from Paying Debts Before Contracted untill 12 years after the Date it will give Roome for men to male Property and not 
statute differed from the subsequent homestead exemption laws in that it protected only land acquired through governmental grant, and this only as against debts contracted prior to its acquisition. To this extent, it might well be considered a prototype of the present federal homestead law, although its purpose was in part different.21

In 1839, after the establishment of the Texan Republic, this statute gave lace to the first of all homestead exemption laws, which has served as a 1odel for later legislation in many other American states. ${ }^{22}$ This law provided that there should be reserved free from execution to each head of a family "fifty acres of land, or one town lot, including his or her homestead or improvements, not exceeding five hundred dollars in value," and also provided for certain chattel exemptions of the type already discussed.2B A similar provision with larger exemptions was incorporated into the Texas constitutions of 1845,1861 and $1866,{ }^{24}$ while in the constitutions of 1869 and 1876 the amount of the allowable exemption was increased still further. ${ }^{25}$ This trend towards an ever increasing liberality is still in evidence at the present day in homestead legislation as a whole. ${ }^{20}$

After 1839, the spread of homestead laws across the country was rapid. Such legislation was adopted by Georgia and Mississippi in 1841,27 by Wisconsin in 1848,28 and by Iowa and Vermont in 1849.20 In the latter year, California placed a homestead provision in its constitution, ${ }^{30}$ while in 1850

be Broke up as it has bin the wish of Some to Buy in the united Staits at and under value those Debts for spacilasion. But I am hapy that thare is astop to all."

21. The underlying policy of this law would appear more nearly in accord with that of the state homestead statutes, which seek rather to preserve the home than to encourage immigration. See notes $62-72$, infra.

22. See Roco v. Green, 50 Tex. 483, 488 (1878); SpeER, Law of Marital Riguts IN Texas (3d ed. 1929) §453.

23. 2 Gamarei, Laws of Texas (1898) 125-126.

24. Under these constitutions, the legislature was empowered to declare exempt from the claims of creditors a rural homestead of not more than two hundred acres or an urban homestead not exceeding $\$ 2,000$ in value. TEX. ConsT. art. VII, $\S 22$ (1845) ; Tex. Const. art. VII, $\$ 22$ (1861); Tex. Const. art. VII, $\$ 22$ (1866).

25. The constitution of 1869 required the legislature to protect from forced sale a rural homestead of not more than two hundred acres or an urban homestead not exceeding $\$ 5,000$ in value at the time of its designation without reference to the value of improvements thereon. TEx. ConsT. art. XII, $\$ 15$ (1869).

The homestead provisions in the present constitution of 1876 are in the main similar to those in the constitution of 1869 , but they also permit a "business homestead" to be held exempt from creditors. TEx. Const. art. XVI, \$§50-52 (1876); NuNN, op. cit. supra note 19 , at $3-5$.

26. Cf. Vance, supro note 2 , at 442 .

27. Cobb, Statutes of Georgia (1846) 100-101; Miss. Laws 1841, c. 15, p. 113.

28. Wis. Laws 1848 , pp. $40-41$.

29. Iowa Laws 1849 , c. 124, pp. 152-153; Vt. Laws 1849 , no. 20, pp. 14-16.

30. CAL. Const. art. XI, $\$ 15$ (1849). 
similar enactments were passed by the legislatures of New York and Ohio.r At the present time, homestead exemption laws exist in all of the states vith the exception of Delaware, Rhode Island and the District of Columbia. Twenty-five states have incorporated these principles into their constitutions. In nine of these, the constitutions require the legislature to pass homestead exemption laws without specifying the details of such legislation, ${ }^{32}$ while the sole provision in the Mississippi Constitution is to the effect that the legislature shall not be prevented from regulating the sale of homesteads. $^{33}$ In Georgia, the debtor is permitted to select either a homestead of the type whose details are set forth in the constitution, or what is termed a statutory "short" homestead, but he cannot have both. ${ }^{31}$ In Utah, the legislature has extended the limits of monetary value set by the constitution upon the homestead, ${ }^{35}$ while in Alabama the maximum acreage established by the constitution for rural homesteads has been increased by legislative enactment from eighty to one hundred and sixty acres. ${ }^{30}$ In the thirteen remaining states, the legislatures have adopted the various constitutional provisions dealing with homestead exemptions. ${ }^{37}$

The statutes themselves present countless diversities. At the present time, the limitations set upon the value of the exempt homestead range from $\$ 100^{33}$ to $\$ 8,000,39$ and those upon the extent of rural acreage from forty ${ }^{43}$ to

31. N.Y. Laws 1850, c. 260, pp. 499-500; Ohio Laws 1850, pp. $29-31$.

32. CAI. Const. art. XVII, $\$ 1$; Colo. Const. art. XVIII, $\$ 1$; III. Const. art IV, § 32; Mont. Const. art. XIX, §4; NEv. Const. art. IV, §30; N. D. Const. art IVII, $\S 208$; S. D. Const. art. XXI, §4; WasH. Const. art. XIX, §1; Wyo. Const. art. $\mathrm{XIX}, \S 9$.

33. Miss. Const. art. IV, $\$ 94$.

34. G৯. Const. art. IX, $\$ 4$.

35. The Utah constitution provides for a homestead of at least $\$ 1,500$ in value. UTAE Const. art. XXII, §1. The legislature has raised this amount to $\$ 2,000$ for the head of the family and has also exempted a further sum of $\$ 750$ for the spoucs, and $\$ 300$ for each additional member of the family. UtaII REv. Stat. ANrv. (1933) \$3\$-0-1.

36. The Alabama constitution exempts a rural homestead "not exceeding eighty acres." ALA. Const. art $X, \S 205$. But the statute enlarging this exemption [ALA CODE ANN. (1928) §7882] has been upheld by the courts. David's Adm'r v. David, 56 Ala. 49 (1876).

37. Ark. Const. art. IX, $\S \S 3-6$; FLA. Const. art. $X, \S \S 1-6$; GN. Const. art. IR, $\$ \S 1-9$; Kan. Const. art. XV, $\$ 9$; LA. Const. art. XI, $\$ \$ 1-4$; Mrcr. Const. art XIV, $\$ \S 2-4$; N. C. Const. art. X, $\$ \S 2-5,8$; OrLA. Const. art. XII, \$\$ 1-3; S. C. Const. art. III, §28; TENN. Const. art. XI, §11; TEX. Const. art. XVI, §§ 5Q-52; VA. Const. art. XIV, §§190-193; W. VA. Const. art. VI, $\$ 48$.

At one time, the Tennessee legislature increased the value of the homestend, as provided for in the constitution, from $\$ 1,000$ to $\$ 2,000$. TExs. Code (Williams, 1932) \$7719. The exemption was again reduced to $\$ 1,000$ in 1933. TExsu. Conz Arnt. (Wrilliams, 1934) §7719.

38. Mid. ANw. Code (Bagby, 1924) art. 83, §8.

39. N. D. Consp. Laws Awn. (Supp. 1925) $\$ 5605$.

40. Iowa CODE (1935) §10136; MIICr. Cosrp. LAws (1929) §14608. 
three hundred and twenty acres, ${ }^{41}$ with one hundred and sixty acres as the most common allotment. Often no differentiation is made between city and country holdings and the sole limitation is one of value, which most commonly is $\$ 1,000.42$ The area of the urban homestead is rarely limited, but where this is done, it is usually set at less than one acre. ${ }^{43}$ While the history of homestead legislation does not appear to be that of a sectional movement, in general, lower exemptions are found in the east than in the south and west. ${ }^{44}$

Not every landowner is entitled to the homestead privilege. To be exempt, the land must ordinarily be occupied as a residence by the debtor and his family, ${ }^{45}$ although in Texas, a "business" homestead may be claimed as well as one for use as a home. ${ }^{46}$ Similarly, the privilege of claiming the exemption is usually restricted to a "householder" or to the "head of a family."47 These terms are rarely defined by the statutes, but where this is done, they are not limited to those in a marital or parental relationship, and are made to include any person who as the result of close kinship is under the moral obligation of supporting those living with him under the same roof. ${ }^{48}$ In California and Idaho, however, homesteads of lesser value may be claimed

41. Mont. Rev. Codes Anv. (Anderson \& McFarland, 1935) §6968.

42. Vance, supra note 2, at 442. The constitutions of Kansas [KaN. Consr. art. $X V, \S 9$ ] and Florida [FLA. Const. art. X, §1], on the other hand, place no limit other than extent upon both urban and rural homesteads. For a criticism of these provisions, see Cole, Homestead Provisions in the Texas Constitution (1925) 3 TEx. L. REv. 217, 222-223.

Where no limit other than extent is set upon the homestead, a subsequent increase in the value of the land will be exempt from creditors. WAPLES, op. cit. supra note 1 , at 218-219. Where the monetary value of the homestead is restricted, there is a conflict of authority as to whether a rise in value will redound to the benefit of creditors. Vanstory v. Thornton, 110 N. C. 10,14 S. E. 637 (1892) (increase in value of homestead held subject to execution); Morton v. Jones, $136 \mathrm{Ky} .797,125 \mathrm{~S}$. W. 247 (1910) (increase in value held immune from creditors); THompson, op. cit. supra note $3, \S 109$.

43. In Missouri, however, the urban homestead may be as large as five acres when the village or town in which it is situated has a population of less than ten thousand. Mo. Stat. Anv. (Vernon, 1932) $\S 608$. In North Dakota, an urban homestead of two acres may be claimed. N. D. CoMp. Laws ANv. (Supp. 1925) §5605.

44. It is significant that some of the eastern states were among the first to adopt this legislation. See notes 29, 31, supra.

45. WAPLES, op. cit. stipra note 1 , at 6 .

46. See note 25 , supra. It has been said that the combined value of these cannot exceed $\$ 5,000$ at the time of designation. See St. Louis Brewing Ass'n v. Walker, 23 Tex. Civ. App. 6, 7, 54 S. W. 360, 361 (1899).

47. WAPLES, $o p$. cit. stipra note 1 , at 57.

48. See, e.g., CAt. Civ. Code (Deering, 1931) §1261; Mont. Rev. Code Ans. (Anderson \& McFarland, 1935) §6969. The exemption privilege is sometimes extended to widows and widowers, though without children, who continue to occupy the family homestead. Iowa CODE (1935) §10151; S. D. CoMp. Laws (1929) $\$ 450$. 
by other than heads of families, ${ }^{40}$ while in Minnesota, Oregon and Wisconsin, the exemption exists in favor of any resident, 50 as is probably true in Vermont where the privilege is granted to any "natural person."

The acquisition of the exemption privilege entails a decrease in the owner's power to transfer his lands freely. Where he is married, the consent of his wife is usually made a prerequisite to the alienation or encumbrance of the homestead. ${ }^{2}$ His power of testamentary disposition is also limited by the provision that upon his death the homestead shall remain exempt from his debts to the use of his widow and minor children. In a few states, the homestead vests in them absolutely, ${ }^{63}$ but in most jurisdictions it descends either by will or to the heirs of the deceased in the normal course of descent and distribution after the widow has died and the youngest child has attained majority. ${ }^{\text {:4 }}$

The statutes usually provide that the homestead may be subjected to sale for the non-payment of certain debts or liens. Preexisting liens and taxes belong almost invariably to this category, and purchase money mortgages, mechanics', laborers' and materialmen's liens, when these are derived from improvements placed on the premises, are often given a privileged status. ${ }^{\text {t5 }}$ Methods are also prescribed whereby creditors can reach the land claimed as exempt to the extent that it exceeds statutory limits. Typically, the creditor may have the land appraised, and if a surplus is found to exist, the surplus may be sold for payment of the debt; or if the character of the land makes such a division impracticable, the entire plot may be sold, reserv-

49. Cal. Civ. Code (Deering, 1931) §1260; Idano Code ANn. (1932) §54-1201. In Georgia, the homestead may be claimed by every "aged, or infirm person" [GA. CoNsr. art. IX, §1], and in Wyoming, by any resident of the state who has attained the age of 60 years. Wyo. Rev. Stat. ANn. (Courtright, 1931) $\$ 89-2984$.

50. Minn. Stat. (Mason, 1927) §8336; Ore. Code Ans. (1930) §3-201; Wis. Stat. (1931) $\$ 272-20$. These statutes are so construed in Ferguson v. Kumler, 27 Minn. 156, 159, 6 N.W. 618, 619 (1880); Smith v. Kay, 153 Ore 80, 90, 54 P. (2d) 1160,1163 (1936) ; Myers y. Ford, 22 Wis. 139, 141 (1867).

51. Vт. PuB. Laws (1934) $\$ 2559$.

52. WapLes, op. cit. supra note 1, at 383. In Georgia and Texas, no valid mortgage can be placed upon the homestead save for the purchase money or for improvements placed upon the premises. GA. Const. art. IX, §2; TEx. Consr. art. XVI, §50. In Georgia, the debtor may waive his right to the exemption at any time before the homestead is formally set apart. GA. Const. art. IX, §3; see IsAnc, Hontestean WatVers and Assignasents (1923) \$\$2-5.

53. Kan. Rev. Stat. Ann. (1923) §22-102; MInns. Stat. (Masan, Supp. 1936) § 8992-27; Utah Rev. Stat. Axw. (1933) §101-4-6.

54. Vance, supra note 2, at 443. In several states, the homestead is exempt from the creditors of the surviving spouse [see e.g., NEB. Coss. Stat. (1929) §40-117; OKLA. Stat. (Harlow, 1931) §1225] and of the minor children [see, e.g., Iows Codz (1935) § 10153].

55. See, e.g., Cat. Civ. Code (Deering, 1931) §1241; GA. Code (1933) §51-101; Vance, supra note 2 , at 443. 
ing to the debtor from the proceeds of the sale the monetary value of the exemption, ${ }^{56}$ often made immune from all execution for a stated period. ${ }^{\text {tr }}$ In several states, creditors are further protected by the provision that the exemption will not take effect until a description of the land is filed with the designated official, ${ }^{68}$ while in Georgia the homestead must actually be set off under the direction of a court of justice. ${ }^{30}$ It is more usual, however, to allow the debtor to claim the privilege at any time before the judicial sale, ${ }^{00}$ while a few states place the levying officer under the affirmative duty to set off the exempt land on his own initiative. ${ }^{61}$

The purposes of homestead laws are apparent in their history and scope. Perhaps their primary objective is to protect the family from the hazards of circumstance or from the improvidence of its head. ${ }^{62}$ Evidence of this may be found in the fact that the exemption inheres only to the family residence and the lands appurtenant thereto; that it can be claimed only by householders with a family; and that the debtor's wife and minor children are protected by restrictions upon his power to alienate or encumber the homestead or to dispose of it by will, the only exceptions to such restrictions being the provisions allowing encumbrances to be incurred in acquiring or improving the home, as in the case of purchase money mortgages, mechanics', laborers' and materialmen's liens. ${ }^{63}$ Another aim of these laws was undoubtedly to protect and encourage home ownership, not only as a

56. See, e.g., ArIz. Rev. Code ANw. (Struckmeyer, 1928) §1735; Irr. ANw. Stat. (Smith-Hurd, 1934) c. 52, \$\$ 10-12.

57. See, e.g., CAL. Crv. CoDE (Deering, 1931) \&1257. The consent of the owner's wife is often a prerequisite to the distribution of the proceeds of the sale. See, e.g., NEv. CoMp. Laws (Hillyer, 1929) §3317.

The proceeds from a voluntary sale of the homestead are often made exempt for a stated period, and in such instances the consent of the owner's wife is also a usual prerequisite to their alienation. See, e.g., NEв. Comp. Stat. (1929) §40-116.

58. See, e.g., La. Gen. Stat. Ann. (Dart, 1932) $\$ \$ 3805,3806$; Nev. CoMp. Laws (Hillyer, 1929) §3315. In some states, the word "Homestead" must be entered in the margin of the record title to the land before the exemption can become effective. See, e.g., Colo. Ann. Stat. (Mills, 1930) §3378-9.

59. GA. CODE (1933) §51-201; cf. N. H. Pus. LAws (1926) c. $214, \S 16$.

60. See, e.g., Ore. Code Anv. (1930) § 3-204; Vt. Pub. Laws (1934) § 2560.

61. See, e. g., Mich. Comp. Laws (1929) §14610; S. D. Comp. Laws (1929) §461.

62. See SPEER, op. cit. supra note 22, § 454; ThoMPSON, op. cit. supra note 3, 81 ; WAPLES, op. cit. supra note 1 , at 3-4. In advocating the adoption of such laws, their proponents in the various constitutional conventions appear to have relied mainly upon the protection which they would afford the debtor's family. "I do think that this idea of homestead is one of the sublimest ideas of our age. It is a principle which has sought form and shape, and come like an angel of mercy to hover over and blesg the families of our nation." Collins, in Proceedings of Constitutional Convention of Nevada (1864) 287. And see Proceedings of Constitutional Convention of California (1849) 269; 1 Proceedings of Constitutional Convention of Illinois (1869-70) 895, 897, 899, 900.

63. See notes $45-55$, supra. 
stimulus to diligence and high morals, but also as a means of enlisting the individual's self-interest in the preservation of established rights and in the promotion of general prosperity.

In the south and west, there were still other reasons for the enactment of such legislation which may account for the larger exemptions existing there. Among these reasons were the frontier conditions and the agricultural character of most of the communities in those regions, factors which naturally lead to the encouragement and facilitation of home ownership. ${ }^{\text {. }}$ Then too, it was felt that homestead laws would redound to the benefit of the small farmer by discouraging the granting of easy credit, which was thought likely to prove disastrous to him. ${ }^{\text {co }}$ The present homestead laws of the southern states date in the most part from the Reconstruction Era, and were largely influenced by the then prevalent distress, ${ }^{07}$ which intensified the demand for debtor-relief and gave the debates in the various constitutional conventions upon this subject the atmosphere of a class struggle. ${ }^{\text {c3 }}$ Conflicting desires as to immigration were further motivating factors behind the liberal exemptions of the south and west, for the southern states hoped to prevent the exodus of their inhabitants by the passage of such laws, vhile their western neighbors sought to attract settlers through the same medin.e?

The modification of the usual incidents of the debtor-creditor relationship worked by homestead legislation has naturally given rise to a formidable

64. See 1 Benton, TaIrTY YeArs' VIEW (1854) 103-104; Joumal of the Reo. John Taylor in 3 O'Callaghay, Docuzrentary History of NEVy Yors (1850) 1136, 1148; Dillon, Homestead Exemption (1862) 10 Arr. L. REc. 641, 647; N. Y. Tribuen, April 11, 1850, p. 4, col. 1.

65. See Roten, op. cit. supra note 2, at 23-24; Vance, supra note 2, at 442

66. See VACHER, op. cit. supra note 4, at 224-225; Poteat, Deblors Exemplions: A Study in Credit Administration (Unpublished thesis in Yale Las School Library, 1933) $28,29,31$. This argument was often used in the various constitutional conventions. See 1 Proceedings of Constitutional Confention of Indtaria (1850) 765, 770-771; Debates of the Constitutional Convemtion of Teras (1845) 421.

67. 6 Rhodes, Histogy of thE UNTIED STATES (1905) 75, 77.

68. "I remember in times gone by the State of South Carolina has been ruled by the rich for the rich. . . . Thank God, we intend to be retrospective, to vips ouf forever, if possible, this terrible heel of despotism." Moses, in 2 Pracezonics or Corrstitutionat Convention of Soutr Carolina (1868) 494, 495. And see Procheommes of Constitutional Convention of Georgia (1877) 4, 86, 450.

Distressed financial conditions were motivating factors behind the adoption of homestead exemption laws in all parts of the country. See Szenson, Land Systears ard Land Polictes in Nebraska (1936) 66, n. 92; Dillon, supra note 64, at 641; 2 PzaCredings of Constitutional Convention of Utä (1895) 1774.

69. See Saryth, Law of Hourestead and Exezrptrons (1875) §14; Stzprensoor, Political History of the Public Lands (1917) 150; Procezonics or Construtuotral Convention of Georgia (1877) 452; 1 Procegdings of Constrtutional. Convzation of Ilumors (1869-1870) 904; 1 Proceedngs of Constitutional Convention of Indiana (1850) 749; 2 Proceedings of Constitutional Conventron of Soutr CarOLINA (1868) 460. 
body of litigation, involving for the most part questions of statutory interpretation. Although the statutes might well be considered in derogation of common law, ${ }^{70}$ the attitude of the courts as a whole has been extremely liberal to the debtor, a liberality which has been carried so far at times as to result in apparent injustice to creditors. This judicial entlutsiasm is actuated in part by a sympathy with poor debtors, but the sentinentality surrounding the concept of "the home" has also had its effect. Many of the earlier opinions attain lyrical heights when the judges mention the family hearth, ${ }^{71}$ and in a recent case, the unashamed romanticism of this attitude found expression in a quotation from "Home, Sweet Home." 72

One prolific source of litigation has been the definition of statutory terms providing who and what property is entitled to exemption. The typical statute does no more than to state in effect that the homestead of each head of the family shall consist of his dwelling house and its appurtenances within designated limits of space and value. Judicial interpretation of these provisions appears to accord in general with the fundamental aims of the legislation. Thus, it is usually held that no particular estate in the land is necessary to entitle one to claim the homestead exemption so long as one has a present right of occupancy, although the exemption is never good against the holder of a paramount title. ${ }^{33}$ Similarly, the terms "householder" and "head of a family" have been made to include all persons who are under a moral obligation to support near relatives living under the same roof. ${ }^{74}$ The

70. Nuns, loc. cit. supra note 19.

71. "The dwelling may be a splendid mansion, or a mere cabin or tent, open to the winds and rains of heaven. If there be either, it is under the protection of the law ..." Hemphill. C. J., in Franklin v. Coffee, 18 Tex. 413, 416 (1857). And see Deere v. Chapman, 25 Ill. 610, 612 (1861); Iken v. Olenick, 42 Tcx. 195, 198 (1875).

72. Cheek v. Walden, 195 N. C. 752, 755, 143 S. E. 465, 466 (1928).

73. Generally, the homestead privilege may be claimed by a lessee [Grattan v. Trego, 225 Fed. 705 (C. C. A. 8th, 1915)], by the holder of a life estate [Wilson v. Devasher, 204 Ky. 408, 264 S. W. 1057 (1924)], by a tenant by the curtesy who is in possession of the land [In re Kaufmann, 142 Fed. 898 (E. D. Wis. 1906)], by the holder of title taken as security [Radford v. Kachman, 27 Ohio App. 86, 160 N. E. 875 (1927)], by the beneficiary of a trust [Jelinek v. Stepan, 41 Minn. 412,43 N. W. 90 (1889)], by the holder of an equity of redemption [Cheek v. Walden, $195 \mathrm{~N}$. C. 752 , 143 S. E. 465 (1928)], and by a person in possession of land under a contract of purchase [Watson v. Poindexter, 176 Ark. 1065, 5 S. W. (2d) 299 (1928)]. Mere possession of the land has been held a sufficient basis for exemption. Hill v. First Nat. Bank, 73 Fla. 1092, 75 So. 614 (1917). The exemption will not, as a rule, attach to future interests. Brooks v. Goodwin, 123 Ark. 607, 186 S. W. 67 (1916). Statutcs sometimes provide that a homestead may be claimed in leaseholds. Sec. c.g., Tens. Code Anv. (Williams, 1934) $\$ 7723$.

74. Davis v. Miami Beach Bank \& Trust Co., 99 Fla. 1282, 128 So. 817 (1930); see Horton v. Gibson, 274 S. W. 292, 294 (Tex. Civ. App. 1925); Vance, supra note 2, at 442. A mere contract relation will not support the exemption. Calhoun v. McLendon, $42 \mathrm{Ga} .405$ (1871) (bachelor living with servants). 
"dwelling house" has also been subjected to its share of judicial interpretation. The usual rule is that while the property to be exempt must be occupied primarily for residential purposes, ${ }^{75}$ the homestead right is not lost by the temporary leasing of a portion of the land, ${ }^{70}$ or by the fact that the premises are partially used for business purposes. ${ }^{77}$ Some courts, however, in professing to follow the literal words of the statute, have held that any land owned by the debtor on which he and his family reside is exempt from his debts, provided it does not exceed the statutory limits. ${ }^{78}$ Such a rule permits the exemption of purely business structures and leads to particularly unfortunate results in those jurisdictions which place no restriction other than extent upon the homestead, ${ }^{79}$ or which merely provide that its monetary value shall not exceed a certain sum at the date of its designation, thus enabling the debtor to hold large sums exempt from his creditors by investing them in improvements upon the premises..$^{60}$

In the absence of express statutory provisions, the courts are called upon to decide what steps must be taken by the debtor in order to become entitled to the exemption. An actual intention to place the land to homestead uses is always a prerequisite, and this must be manifested by overt acts before it can become effective. ${ }^{81}$ Occupancy of the land will usually fulfill this requirement, ${ }^{82}$ while in some states, the mere intent to occupy certain lands as a homestead, when coupled with overt acts of preparation, is held sufficient if actual occupancy follows within a reasonable period. ${ }^{83}$ A similar question

75. Harris v. Carlson, 201 Iowa 169, 205 N. W. 202 (1925); see WArzEs, op. cit. supra note 1 , at 6 .

76. Succession of Veronie, 147 La. 12, 84 So. 439 (1920). Staturtes sometimes provide that the temporary renting of the homestead will not vitiate the exemption so long as no other homestead has been acquired. See, e.g., OrLı. St八t. (Farlow, 1931) $\S 1643$.

77. McKay v. Gesford, 163 Cal. 243, 124 Pac. 1016 (1912) (premices used as a hotel); Rush v. Gordon, $38 \mathrm{Kan} .535,16 \mathrm{Pac} .700$ (1888) (grocery store in lower story). Some statutes provide that a shop located on the premises and uced by the owner in his daily business is properly appurtenant to the homestead. See, e.g., Iowa CODE (1935) § 10137.

78. In re Tertelling, 23 Fed. Cas. No. 13,842 (C.C. D. Kan. 1872) (brewery held exempt); Lockey v. Lockey, 112 Minn. 512, 128 N.W. 833 (1910) (homestead could be claimed in four separate tenements since total area was within statutory limits).

79. See Jacoby v. Parkland Distilling Co., 41 Minn. 227, 43 N. W. 52 (18S9) (business building worth $\$ 24,000$ declared exempt); Phelps v. Rooney, 9 Wis. 70 (1859) (business building declared exempt).

80. Chase v. Swayne, 88 Tex. 218, 30 S. W. 1049 (1895) (improvements placed on homestead and valued. at $\$ 125,000$ declared exempt); King v. Hapgood Shoe Co., 21 Tex. Civ. App. 217, 51 S. W. 532 (1899) (debtor constructed building with non-exempt funds, for purpose of defrauding creditors).

81. NunN, op. cit. supra note 19 , at 99 .

82. Barto v. Kellogg, 289 Ill. 528, 124 N. E. 633 (1919) ; Evansville Coffin Co. v. Sumner, 189 Ky. 839, 226 S. W. 363 (1920).

83. Mandan Mercantile Co. v. Sexton, 29 N. D. 602, 151 N. W. 780 (1915); Benzel v. Commercial Nat. Bank, 1 S. W. (2d) 695 (Tex. Civ. App. 1927). 
arises as to what is to be deemed an abandonment of the exemption privilege. It is generally held that the land will not lose its homestead character until it is actually abandoned by the debtor and his family with the intention of never again using it as a homestead. ${ }^{84}$ The burden of proving this intent is upon him who seeks to show the abandonment, and to meet this burden, where no new homestead has been acquired, a high degree of proof is required..$^{85}$ It has often been held, even in the absence of express statutory authorization, that the proceeds from a voluntary sale of the exempt land will remain immune from creditors for a reasonable period if held with the purpose of purchasing a new homestead. ${ }^{80}$

In certain instances, the courts seem to have been unduly harsh on creditors, although their rulings were not impelled by the literal wording of the statutes. ${ }^{87}$ The view is taken by many jurisdictions that a contract for the sale of the homestead is wholly void if it has been entered into without the consent of the owner's wife, and that consequently the would-be purchaser can recover no damages for its breach. ${ }^{88}$ The equitable rule of marshalling assets has also been held inapplicable where a homestead right is involved, so that the debtor may lawfully insist that a creditor whose lien covers the homestead and other lands as well shall first resort to the non-exempt lands even though the security of other creditors in the same land is thereby impaired or destroyed. ${ }^{89}$ Moreover, the motivating factors behind the selection of the particular homestead have in large measure been disregarded by the courts. Thus, a debtor is permitted to purchase a homestead with nonexempt funds for the express purpose of defeating the just claims of his creditors, ${ }^{, 0}$ or he may designate as his homestead land which he had previously assured them could be subjected to sale for the non-payment of his debts. ${ }^{91}$

84. Dean v. Cole, 141 Ark. 177, 216 S. W. 308 (1919) ; Ritz v. First Nat. Bank of Pecos, 234 S. W. 425 (Tex. Civ. App. 1921). In some states a formal declaration of abandonment is necessary in order to relinquish the exemption privileges. See, e.g., Idamo Code Ann. (1932) §54-1007; Mont. Rev. Codes Ann. (Anderson \& McFarland, 1935) $§ 6951$.

85. Carstens v. Landrum, 5 S. W. (2d) 208 (Tex. Civ. App. 1928); see (1936) 12 Wis. L. REv. 121.

86. Note (1919) 1 A. L. R. 483. It is generally held that property received in exchange for the homestead is exempt if it is to be used as a family home. Note (1933) 83 A. L. R. 54.

87. At one time, the Georgia courts gave a retroactive effect to their statute. See Chambliss v. Phelps, 39 Ga. 386 (1869); Hardeman v. Downer, 39 Ga. 425 (1869). But the Georgia statute as thus construed was declared unconstitutional. Gunn v. Barry, 15 Wall. 610 (U. S. 1872), rev'g 44 Ga. 351 (1871).

88. Notes (1919) 4 A. L. R. 1272; (1922) 16 A. L. R. 1036.

89. Boyce v. Hawn, 52 S. D. 53,216 N.W. 589 (1927); Burg v. Hitzfield, 89 S. W. (2d) 272 (Tex. Civ. App. 1935).

90. Hale v. Richards, 80 Iowa 164, 45 N. W. 734 (1890); Dotson-Murray Fruit Co. v. Liebrand, 143 Kan. 72, 53 P. (2d) 487 (1936).

91. Jacoby v. Parkland Distilling Co., 41 Minn. 227, 43 N. W. 52 (1889). 
Although homestead laws were American in origin, they are now paralleled by more or less similar legislation elsewhere, the similarity being most marked where conditions resemble those of the western portions of the United States. In Alaska, the debtor is given an exemption up to one hundred and sixty acres of rural land or one-quarter of an acre in the city, but the total value of either cannot exceed $\$ 2,500.02$ Hawaii permits an exemption of one acre of land whose value along with that of the buildings situated thereon is limited to $\$ 1,000.03$ In the Philippines and Porto Rico, no other limitation is set upon the homestead than that of value, the limit in the former case being 150 pesos, and in the latter, \$500.st Lavs closely resembling the American model have been passed in the Canadian provinces of Alberta, British Columbia, Manitoba and Saskatchewan, and in Nev Zealand and South Australia.95 Brazil and Venezuela have also enacted laps which are similar to ours except that they set no fixed limits upon the homestead. .8

In Europe, a strong movement for homestead exemption laws has existed since the last quarter of the nineteenth century, caused by the prevailing economic distress of that period, which proved the ruin of many small cultivators and drove them to the cities. ${ }^{07}$ A primary purpose of these laprs, apart from their humanitarian objectives, was to stimulate the culture of the soil and to prevent the depopulation of rural areas, although in France, Belgium and Switzerland they were also connected with housing programs.53 The European homestead laws usually demand registration of the lands and other formalities as a prerequisite to gaining the exemption, and also, as a probable result of their agrarian tendencies, place far greater restrictions on the alienation and encumbrance of the homestead than is done in the United States.

Switzerland in 1907 was the first European country to pass a homestend exemption law modelled after the American type. ${ }^{00}$ This law, which did not

92. Araska Congr. Laws (1933) §3723.

93. HawaII REv. LAwS (1935) $\S 4160$.

94. Prit. Cone Crv. Proc. (Fisher, 1925) §452; P. R. Cozrp. Rer. Stat. Ez Coses (1913) $\S \S 1000-1005$.

95. 2 Alberta Rev. Stat. (1922) 1113-1115; 1 Britis (1924) 1345-1348; 2 Manitoba Rev. Stat. (1913) 1025-1029; 1 Sastatchevirat Rrp. Stat. (1930) 801-808; 3 New Zealand Public Acts (1908-1931) 292-293; South Australia Laws 1895, no. 10.

96. Brazil: Law No. 3,071 of January 1, 1916, 1916 Copico Crrn art 8670-73; Venezuela: Coprgo Crvin (June 26, 1922) art. 614-624.

97. Roten, op. cit. supra note 2 , at 26 .

98. 3 WoLf, LeHrbucr Des Büzgeruiches Recers (9th ed. 1932) 319. Thas laws apparently have not proved popular in France and Svitzerland In France, caly 249 families had established homesteads by 1921. See BrUTNEs ard 21AYZs, Herispstättenrecht in 4 RECHTSVERGLEICHENDES HANDWÖETREDUCB (1933) 221.

99. Swiss Crvil Cone (1907) (Schick, 1915) art 349-359. 
become effective until 1912, empowers the cantons, on application by the prospective homesteader, to create rural or urban homesteads subject to certain limitations. No restrictions are laid upon the amount or value of the land permitted to be held as exempt, save that it cannot exceed the size necessary to furnish reasonable support to the owner and his family. The rights of existing creditors are carefully protected, for notice of the application for the exemption must be published, special notice being required for all lien holders, and if any creditors object, the homestead may not be created until the debts owed them have been paid. Furthermore, the exemption does not become effective until it is entered in the land register, which is published officially as an added safeguard for future creditors. The land can neither be alienated nor encumbered once it has been impressed with the homestead character, but the owner can procure the dissolution of the exemption by petitioning the proper official, which petition must be published in order to give notice to all interested parties before the cancellation may be decreed. The immediate family of the owner is further protected by the peculiar provision that the homesteader can be forced to provide a shelter for his blood relatives in the ascending and descending lines, and also for his brothers and sisters, if in abject poverty and worthy of support. The homestead exemption ceases at the death of the owner unless he has given directions in his will for its continuance. The privilege of exemption cannot pass by intestacy.

The French homestead law of 1909 closely resembles that of Switzerland except that the value of the property is limited to 8,000 francs at the time of its designation as a homestead. ${ }^{100}$ This statute also safeguards creditors by requiring that notice of the application for the exemption be published in a newspaper at certain intervals for a period of two months before the application itself can be acted upon by a court. The alienation or encumbrance of the land is forbidden unless the owner's wife consents before a justice of the peace, or if no wife survives and there are minor children, the "family council" must consent, which it is admonished not to do unless the children will clearly benefit thereby. Where the homesteader dies leaving minor children, the justice of the peace may at his discretion decree the continuance of the exemption until the youngest child attains his majority.

The German homestead law of May 10, 1920, is not restricted to agricultural holdings, but one of its primary purposes appears to be agrarian. ${ }^{101}$ A homestead is created either by the purchase of land from the so-called "Ausgeber" 102 or by an agreement with the "Ausgeber" whereby land al-

100. France: 2 Codes et Lois pour la France et les Colonies (Colin, 20th ed. 1925) $1359-1360$.

101. Germany: Law of May 10, 1920, 1920 Reichscesetzblatt 962. The German Constitution of 1919 provides for such legislation. Reichsverfassung (August 11, 1919) art. 155. See 3 WolfF, op. cit. supra note 98 , at 319-322.

102. The "Ausgeber" may be the Reich, one of the particular states, a municipality, or a duly authorized public corporation. 
ready owned by the beneficiary takes on the homestead character. In either event, severe restrictions are placed upon the homesteader's power to deal freely with his land. He can neither divide nor encumber it without the consent of the "Ausgeber." The "Ausgeber" is also empowered to buy the land in cases where an attempt is made to sell it to anyone save a near relative, or where the owner desires to deed the land away as a gift, does not reside permanently upon it, fails to cultivate it, or does so badly. Once the homestead is created, the land is exempt from all creditors save mortgagees.

An Egyptian law of 1912 is also agrarian in scope, since it restricts the privilege of exemption to those cultivators who own no more than five feddans of land and includes two drawing animals and all necessary agricultural implements. ${ }^{103} \mathrm{By}$ this law, the debtor is not permitted to renounce the exemption. Homestead laws are also to be found in several of the Ballean countries. ${ }^{104}$ These laws are likewise confined to restricting the sale or encumbrance of agricultural lands.

The most significant recent development in this field is to be found in a movement in the United States to exempt the homestead from taxation. This trend, having its origin in the recent difficulties of home orners, ${ }^{105}$ has thus far been embodied in the constitutions or laws of nine states, with exemptions ranging from $\$ 1,000$ to $\$ 5,000$ of the actual or assessed value of the homestead. ${ }^{106}$ Two other states have provisions either for the assessment of homesteads at a lower percentage of real value or for their taxation at a lower percentage of their assessed value. ${ }^{107}$

103. Egypt: Law No. 31 of 1912, 2 Codes Egypriens (Wathelet \& Brunton, 1919) 553.

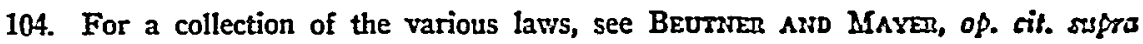
note 98 , at 226-229.

105. See Logan, Oklahoma Tax Exemption Law (1936) 14 TAx MAa. 79.

106. ARK. Const. amend. 23, adopted Nov. 3, 1936 ( $\$ 1,000$ exemption, which legislature may increase to $\$ 2,500)$; FLA. Const. art. $X, \$ 7$ ( $\$ 5,000$ exemption); IA. Const. art X, $\S 4$ ( $\$ 2,000$ exemption); Miss. Laws Ex. Sess. 1935, c 22 ( $\$ 2,500$ exemption); N. M. Const. art VIII, $\$ 5$ (legislature may exempt up to $\$, 500$ ); N. C. Const. art. V, $\S 5 ;$ N. C. Pub. Laws 1935, c. 444 (legislature may exempt up to $\$ 1,000)$; OrLa. Const. art. XIII, $\$ 13673$ a-b (legislature is empowered to determine amount of exemption; this amount may not be decreased for twenty years, but may be increased); TEX. Const. art. VIII, $\S 1$ la ( $\$ 3,000$ exemption); UTAn Const. art. XIII, $\S 2$, S.J.R. No.2 (Feb. 5, 1935) (legislature may exempt up to $\$ 2,000$ ).

In all of these states, with the exception of Utah, the exemption is apparently baced upon the assessed valuation of the land.

Constitutional amendments providing for homestead tax exemptions were rejected by referenda in Arkansas and Mifichigan in 1932 and in New Mfexico in 1935. RESENrCB Departasent, Kansas Legislative Council, Hourestead Tax Exeustion (Preliminary Statement 1936) 5.

107. Mrnv. Stat. (Miason, Supp. 1936) \$1993. The first $\$ 4,000$ in value in all homesteads is assessed at $20 \%$ of true value if unplatted, and at $25 \%$ if platted. Other 
The chief legal problem raised by these provisions which has as yet been passed upon by the courts is whether homesteads can constitutionally be released from taxation altogether. ${ }^{108}$ It has been held in several recent cases that they must remain taxable at least to contribute to the payment of interest and principal on bonded debts issued prior to the enactment of the exemption provisions. ${ }^{109}$ As a result, exemption laws may prove of advantage to the bondholders who can mandamus a tax levy on homesteads which will be wholly for their benefit. Indeed, the claim has been made that the Florida tax exemption statute was promoted by bondholders. ${ }^{110}$

The justification for the tax exemption statutes is based largely on the same grounds as those advanced in support of the older homestead laws: it is hoped that they will encourage home ownership as a means of preserving the family, high moral standards, and democratic institutions, attract outsiders into the state, and induce local residents to remain.111 It can also be urged that since the exemption will result in a proportionately greater reduction in taxes for the owner of low-valued than of high-valued property, these statutes will aid in correcting the almost universal tendency to assess low-valued property at a higher percentage of full value than high-valued property, thus bringing the tax system more nearly into accord with the principle of ability to pay. ${ }^{112}$

On the other hand, the statutes are open to several serious objections. One of the most important is their probable effect on governmental revenue.118

real estate is assessed at $40 \%$ if platted and at $331 / 3 \%$ if unplatted. This statute has been upheld by the courts. Apartment Operators Ass'n v. Minneapolis, 191 Minn. 365, 254 N. W. 443 (1934), (1934) 18 Mins. L. REv. 751; Logan v. Young, 191 Minn. 371, 254 N.W. 446 (1934). W. VA. Const. art. X, §1. Homesteads are taxed at 1\% of their assessed value. Non-homestead property is taxed at $11 / 2 \%$ if without, and at $2 \%$ if within a municipality.

108. Other problems which are likely to vex the courts include such questions as what constitutes ownership within the meaning of the statutes, and what parties shall be entitled to bring suit in order to enforce or enjoin the levying of taxes upon homestead property. See Comment (1937) 15 N. C. L. REv. 211.

109. Folks v. County of Marion, 121 Fla. 17, 163 So. 298 (1935); State v. City of Pensacola, 123 Fla. 331, 166 So. 851 (1936); State v. City of Orlando, 170 So. 887 (Fla. 1936); Keeney v. County Court, 115 W. Va. 243, 175 S.E. 60 (1934).

110. Researce Departaent, Kansas Legislative Councit, op. cit. supra note 106, at 13-14; see Tampa Daily Times, Oct. 10, 1934, p. 6, col. 1.

111. Brandis, Proposed Changes in the State Constitution (April, 1936) in 3 PopuLAR Gov't 17. Doubts have been expressed as to the efficacy of these laws in attracting non-residents into the state. See Research Departaent, Kansas Legislative Councti, op. cit. supra note 106 , at 15 .

112. See Investigating Compittee of Uta Governmental Units, Report on the Homestead Exemption Proposal (1936) 147.

113. Mississippi is one of the states for which a full year's actual experience with homestead exemption is available. With a $\$ 1,000$ exemption [Miss. Laws 1934, c. 191], the exempt property was approximately $9 \%$ of the total property assessment. REsEARcu Departament, Kansas Legislative Councit, op. cit. supra note 106, Supplementary 
The total amount of homestead property may be comparatively insignificant as a source of state income;114 but, while actual experience is still lacking, several surveys have been made which indicate that the loss of revenue will fall most heavily on the counties and school districts, and will in many instances be so great as to necessitate their being financed in part by the state, unless assessments or taxes are increased. ${ }^{115}$ The problem of reimbursing the various units will be particularly difficult, for the surveys show that the reduction in revenue will vary greatly from one taxing district to another of the same grade, since local districts having a high percentage of tenancy, or of public utility property, or which consist of a fev extensive holdings of real estate will be less affected than those consisting of a large number of holdings assessed at approximately the exemption amount. In general, it can be supposed that the smaller and poorer city and county governments will lose relatively the most.110 Louisiana appears to be the only state which at the present time has made adequate provisions for the reimbursement of the local taxing units. This reimbursement is made. on the basis of their actual loss which is directly attributable to the exemption, and is to be paid from a "Property Tax Relief Fund" to whose credit the proceeds of certain taxes are to be deposited. The amounts of the various exemptions are made dependent upon the size of the fund thus available, but in no case may they exceed $\$ 2,000.117$

Apart from the financial difficulties which the tax exemption laws may cause for local taxing units, it may be questioned whether the exemptions will make for a desirable allocation of the tax burden. This will of course depend upon the type of tax with which the lost revenues are to be replaced. ${ }^{118}$ In this connection, it may be noted that home orfners as a class

Report at 22-23. The Mississippi legislature subsequently increased the exenption to $\$ 2,500$. Miss. Laws Ex. Sess. 1935, c. 22.

114. See Researci Departatent, Kansas Legislative Coutucto, op. cit. sispo

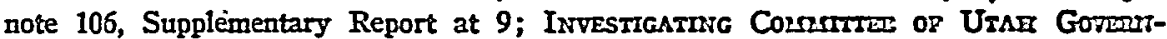
IIENTAL UnITS, op. cit. supra note 112, at 54; Brandis, suspra note 111, at 18.

115. According to the Alabama survey, only five counties would shor a current operating surplus in the general fund if an exemption of $\$ 2,000$ were adopted. Kurrcrs, Effect of Proposed Hourestead Exemption (1936) 7; see Logan, siffo note 105, at 80 .

116. See Research Departzrent, Kansas Legislative Counct, op. cit. sispo note 106, Supplementary Report at 25-26.

117. LA. Const. art. X, §4; LA. GEN. Stat. ANN. (Dart, Supp. 1935) 83505 .1-.5. The state has thus far been able to provide only for a $\$ 1,000$ exemption. This is possibly the result of a tendency on the part of the local assessors to assess homestends at the maximum exemption allowance, thus increasing the amount of reimburement due from the state to the various counties. Communiation received by the TAII LAD Journal from the Baton Rouge Morning Advoeate, Dee 26, 1936.

118. Martin, Social Aspects of Tas Exemption (Jan. 1936) Ammars 43, 53. 
are frequently among the more prosperous members of the community, so that the property tax, with all its inequalities, tends to conform more nearly to the principle of ability to pay than the sales tax, a measure to which state legislatures have recently been quite willing to turn in their efforts to overcome deficits. ${ }^{118}$

Criticisms may also be voiced on other scores. In the first place, the exemption laws appear to offer numerous opportunities for tax evasion. For example, it will undoubtedly prove difficult to prevent nominal transfers of property whereby individuals without bona fide homesteads will secure tax exemptions for large land owners. ${ }^{120}$ And since it is generally held that occupancy of land under a contract to purchase confers homestead rights, many landlords may be able to escape taxation by changing from a rental to a "contract to purchase" basis, which will give a homestead status to rented property. ${ }^{121}$ Secondly, it can be contended that a mere tax exemption will enable but few persons to become homesteaders, since it can prove of no advantage to those who have not as yet accumulated sufficient capital.122 Finally, if it is desirable to encourage home ownership by offering monetary inducements, a direct subsidy would seem preferable to a tax exemption, the exact amount of which is difficult to determine and which is in the nature of a continuing subsidy not subject to periodic review, so that it may continue long after it has ceased to be justified. ${ }^{123}$

It may be that the social needs served by the homestead exemption movement, embodied in legislation all over the world, and warmly supported by the courts, have become less urgent and universal, in view of the changing status of the family, ${ }^{124}$ and the revolution which has taken place in the habit of home ownership. Homestead exemption laws serve little purpose in great cities where most housing is rented $;^{125}$ it seems safe to predict that whatever utility such legislation will have in the future will be restricted largely to

119. See Seligman, Essays in Taxation (9th ed. 1921) 478; Research DeraktMeNt, Kansas Legislative Council, op. cit. supra note 106, at 8; Salt Lake Tribune, Feb. 7, 1936, p. 20, col. 1 .

120. Martin, loc. cit. supra note 118.

121. Research Department, Kansas Legislative Council, op. cit. supra note 106, Supplementary Report at 12 ; see note 73 , supra.

122. Logan, supra note 105 , at 80 .

123. See Researce Departanent, Kansas Legislative Council, op. cit. sitpra note 106 , at 8 .

124. See Wallis and Wiliey, Readings in Sociology (1930) 403-404, 408-410.

125. A homestead may generally be claimed in leaseholds, but it provides no protection against the claims of the landlord. See Thompsos, op. cit. supra note 3 , \&176; note 73 , supra. In view of the relatively short duration of a term for years, the exemption could hardly prove of great advantage to the debtor. See WAPLES, op. cit. supra note 1, at 115 . 